\title{
A COMPARATIVE STUDY OF PROFESSIONAL WELL- BEING IN AGENCY AND FREELANCE TRANSLATORS
}

\author{
Klaudia Bednárová-Gibová1 \\ Mária Majherová 1 \\ ${ }^{1}$ University of Presov, Presov, Slovakia
}

\begin{abstract}
Departing from a sociological paradigm shift and the contemporary appeal to re-humanize translation studies, the paper anthropocentrically zooms in on agency translators and freelancers as important actors of translation practice. In the attempt to highlight translators as human beings with their voices and feelings in their uneasy occupational realities, the paper aims to compare professional well-being in agency and freelance translators based on four Dam and Zethsen's status parameters and psychological variables of happiness at work (HAW). The paper reports results of a questionnaire-based survey completed by 93 agency translators and 84 freelancers in Slovakia. The translator's self-perceptions of the selected variables are compared using measures of central tendency and their HAW profile emanates from a correlation analysis. The results of the analysis imply that the studied minor language translators show comparably high levels of professional well-being although they slightly differ in some 'facet-specific' happiness. Although embedded in the Slovak translational reality, an analysis of the translators' professional well-being uncovers important specificities of the minor socio-psychological identities which can contribute to a research puzzle of the particularities of translators' professional well-being in major linguocultures. The paper points to the added value of integrating insights from psychology into sociological TS research, thus creating a common reflection space.
\end{abstract}

Keywords: Agency Translators; Freelancers; Job Satisfaction; Sociology of Translation; Translator Psychology 


\title{
ESTUDO COMPARATIVO DE BEM-ESTAR PROFISSIONAL DOS TRADUTORES QUE TRABALHAM PARA AGÊNCIAS DE TRADUÇÃO E DOS FREELANCERS
}

\begin{abstract}
Resumo: Partindo da alteração do paradigma sociológico bem como do desafio contemporâneo de reumanizar os estudos de tradução, o artigo põe antropocentricamente em destaque os tradutores que trabalham para agências de tradução e os freelancers enquanto atores eminentes da prática da tradução. Na tentativa de realçá-los enquanto seres humanos dotados de opiniões e sentimentos no quadro duma realidade laboral nem sempre fácil, o artigo tem como objetivo comparar o bem-estar profissional dos tradutores que trabalham para agências de tradução e dos freelancers baseado nos quatro parâmetros do estatuto de Dam e Zethsen e nas variáveis psicológicas da felicidade no trabalho (HAW, happiness at work). $\mathrm{O}$ artigo descreve os resultados dum inquérito com base no questionário preenchido por 93 tradutores que trabalham para agências e 84 tradutores freelance na Eslováquia. As próprias perceções dos tradutores das variáveis selecionadas são confrontadas através das medidas de tendência central e o seu perfil HAW resulta duma análise de correlação. Os resultados da análise sugerem que os tradutores de línguas pequenas estudados acusam níveis comparativamente elevados de bem-estar profissional embora apresentem ligeiras diferenças na felicidade ao nível de algumas das facetas. Apesar de ser inserida na realidade eslovaca das traduções, uma análise de bem-estar profissional dos tradutores revela importantes especificidades das pequenas identidades sociopsicológicas suscetíveis de contribuir para o enigma de investigação das particularidades do bem-estar profissional dos tradutores das grandes linguaculturas. $\mathrm{O}$ estudo aponta para o valor acrescentado da integração dos conhecimentos da psicologia na investigação sociológica dos estudos de tradução criando assim um espaço de reflexão comum.
\end{abstract}

Palavras-chave: Agência de Tradutores; Freelancers; Satisfação no Trabalho; Sociologia da Tradução; Psicologia do Tradutor

\section{Introduction}

Following Chesterman's “agent model” (2009) promoting focus on translators and Bolaños-Medina's appeal (2016) to integrate psychological aspects into translation studies (henceforth TS) research, this study deals with translators' professional well-being, 
i.e. their domain-specific happiness. Even though job satisfaction has been studied within positive and organizational psychology as well as human resources management for a long time, in-depth research into translators' job satisfaction remains scarce.

The present study looks at translators in disagreement with the "Easterlin paradox" which signifies the relationship between the growing physical wealth and decreasing personal happiness (Klamár; Gaval'ová 315). A number of studies unanimously portray translators as low-income individuals (e.g., Courtney \& Phelan; Moorkens) with low degrees of influence, status and professional visibility (Dam \& Zethsen, "The Status of Professional Business Translators") who are, however, quite satisfied with their job (Dam \& Zethsen, "I Think It Is a Wonderful Job"; RodríguezCastro, "Intrinsic and Extrinsic Sources"; Courtney \& Phelan; Bednárová-Gibová \& Madoš). This paradoxical situation, challenging the Easterlin paradox in regard to the translator habitus, only underscores the "conflict between translators' own work being appreciated and the profession at large being undervalued" (Ruokonen \& Mäkisalo 14). Against this backdrop, we set out to compare professional well-being in Slovak freelancers and agency translators based on selected status parameters and psychological variables of HAW. Our goal is also to identify the resources of their job satisfaction. The choice of freelancers has been motivated by recent changes on the global translation market supporting the vendor model, which promotes freelancing as the preferred type of employment in translators (Moorkens 55). However, freelancers in this study are understood as sole traders who translate for direct clients whereas agency translators are full- or part-time salaried translators who translate for agencies.

In what follows, Section 2 offers a review of previous research, Section 3 clarifies operationalization of the conceptual construct of domain-specific happiness (whatever the label), and section 4 addresses the methods and description of the survey. The outcomes of the quantitative (and partly also qualitative) analysis are presented in Section 5, followed by a discussion in Section 6. 


\section{Previous research}

Investigations into translators' professional well-being/jobsatisfaction or domain-specific happiness (see section 3) have recently formed the subject of interest of the sociology and psychology of translation. According to a $\mathrm{Ng}$ and Feldman's meta-analysis, research into job satisfaction and subjective career success based on cognitive and affect-based indicators has become more widespread than explorations of objective career success ( $\mathrm{Ng} \&$ Feldman). Although job satisfaction has been thoroughly studied in relation to a great many professions, translators as agents of the relatively marginalized language industry have received far less attention.

Katan's international surveys ("Translation Theory and Professional Practice" and "Occupation or Profession") rank among the first pieces of translator research to have brought up the issue of job satisfaction. Katan's research participants reported high or very high degrees of job satisfaction in both meta-studies and appreciated the stimulating character of translating.

Liu, drawing on her doctoral thesis, provides us with the first attempt to empirically examine the translator's job-related happiness with a focus on Chinese translators. She approaches translators' job satisfaction via Bourdieu's capital theory and finds out that that the more visible the translator, the happier they are, and the less the gap between capital sought and received (Liu).

Relevant for this study, Dam and Zethsen ("The Status of Professional Business Translators") compare three groups Danish translators - company, agency and freelance translators, employing parameters of education/expertise, visibility, power/influence and salary/income to examine their perceived level of occupational prestige. Their research reveals that freelancers rank poorly in terms of visibility and power/influence especially in comparison to company translators, but they count the highest income levels despite the lowest status perceptions. Similarly to Katan's findings ("Occupation or Profession”), Dam and Zethsen view translating highly positively as "a varied, stimulating, and never boring" activity bringing 
intellectual challenges (Dam \& Zethsen, "I Think It Is a Wonderful Job" 180). They also consider the "feeling of translating" "a more indefinable source of satisfaction" (ibid. 181). This corroborates the author's psychological observation that translators seem likely to experience "linguistic hedonism" as they often "derive a sense of pleasure from working with words” (Bednárová-Gibová, "Exploring the Literary Translator's Work-related Happiness" 77).

Concerning translator satisfaction and its measurement, Rodríguez-Castro ("Development and Empirical Validation” and "Intrinsic and Extrinsic Sources") must be credited with developing the first instrument for gauging translators' job satisfaction, focusing on its intrinsic and extrinsic sources, employing Herzberg's twofactor framework. In the sequel to the first study, which does not indicate any significant results, she concludes that important sources of task satisfaction in translators involve intrinsic pride in one's work, ability to perform a wide range of tasks and successful project completion. Leading sources of job satisfaction are related to team members' professional skills and a respectful relationship with clients whereas low income makes for the major source of dissatisfaction (Rodríguez-Castro, "Intrinsic and Extrinsic Sources").

More recently, some empirical studies set out to examine the relationship between job satisfaction and stress (e.g., Ruokonen \& Mäkisalo; Courtney \& Phelan). Ruokonen and Mäkisalo (13) argue that a low perception of the translator's status is connected with more work-related stress and leaving the profession more frequently. Courtney and Phelan's research identifies on the one hand four sources translators' occupational stress, i.e. poor treatment from agencies and clients, issues with remuneration and employment, uncertainty about the future and tight deadlines. On the other hand, their research indicates that flexibility and autonomy, positive feedback from clients as well as the art and craft of translation per se, resulting in high quality language production, imbue translators with a sense of accomplishment.

Tracing translators' primary satisfiers, Moorkens reports a strong sense of pride in his sample of Irish translators, but draws attention 
to the fact that freelancers' self-concepts of purpose and fairness in their work, payment and job security compare poorly with those of salaried translators. Simultaneously, the majority of freelancers feel jeopardized by technology and machine translation. In the latest study by Ruokonen, Lassus and Virtanen (2020), respondents concur that being engaged in meaningful tasks, having the possibility to influence the tone and quality of the translation, and colleagues and social contacts constitute major resources of job satisfaction.

To sum up, previous research shows that translators seem generally satisfied with their job although major sources of satisfaction range from the nature of translating (Katan, "Occupation or Profession"; Rodríguez-Castro, "Intrinsic and Extrinsic Sources"; Dam \& Zethsen, "I Think It Is a Wonderful Job"), pride in work (Rodríguez-Castro, "Intrinsic and Extrinsic Sources"; Moorkens) up to contacts and relationships (Liu; Rodríguez-Castro, "Intrinsic and Extrinsic Sources"; Ruokonen, Lassus and Virtanen). In this study we examine how our data contribute to the self-concepts of translators' professional well-being. We delve into the importance of the translator's job as an identity marker and put it in perspective in relation to the selected variables affecting domain-specific happiness. We zero in on freelancers and agency translators in Slovakia as minor language translators whose happiness at work (HAW) profiles have not been explored yet. Prior research across the Slovak social landscape within the HAW undertaking was targeted only at sworn and institutional translators (Bednárová-Gibová \& Madoš; Bednárová-Gibová, "How Happy are Legal Translators?”) and their literary peers (Bednárová-Gibová, "Exploring the Literary Translator's Work-related Happiness").

\section{Professional well-being/job-satisfaction/domain-specific happiness or HAW}

In order to clarify conceptual operationalization of the vague psychological and philosophical construct of happiness, we have 
to look at its onomasiological aspects first. Well-being, satisfaction with life, subjective comfort or quality of life are generally used synonymously (see e.g., Klamár; Gaval’ová), although some scholars find it important to draw a line between these concepts (Warr, "Work, Happiness and Unhappiness"). Applying Chesterman's (2019) approach to conceptual categories, it becomes evident that within the well-being undertaking we are dealing essentially both with splitter as well as lumper concepts ${ }^{1}$ foregrounding differences or similarities, respectively. Warr notes that that the broader term well-being, evidently favoured by academics, includes also physical, social, economic and spiritual aspects, transcending the subjective in happiness (Warr, "The Psychology of Happiness”).

Moreover, current occupational research emphasizes the urgency of conceptualizing happiness at work (HAW) with its broad semantic extension in regard to the evaluation of job characteristics (job satisfaction), passion and energy at work (engagement), and connection with an organization (affective organizational commitment) especially in knowledge-intensive workers (Salas-Vallina et al.).

Abstaining from "context-free happiness" with a general reference, this study makes use of Warr's ("Searching for Happpiness at Work.") "domain-specific happiness", tackling translators' feelings in a targeted domain (job satisfaction), coupled with "facet-specific happiness" (addressing particular aspects of the domain, e.g., translators' income). We also focus on translators' longer-term well-being, extending across time, rather than "situational well-being" within a short period (Warr \& Nielsen). Because of essentially identical denotative content despite differences in the semantic scope of terms and their connotative potential, we use professional well-being/job satisfaction/ domainspecific happiness/HAW more or less interchangeably in this study.

In the absence of general consensus about the most appropriate definition of HAW, our denotative interpretation of the term at

${ }^{1}$ See Chesterman's discussion (“Moving Conceptual Boundaries” 12-19) of platypus, splitter, lumper and rebranding concepts when addressing conceptual innovations.

Cad. Trad., Florianópolis, v. 41, n⿳2 2 p. 109-136, mai-ago, 2021. 
hand relates to translators" "experience of subjective well-being at work that involves contentment, positive assessment of aspects of their professional lives and preponderance of positive over negative feelings" (Bednárová-Gibová, "Exploring the Literary Translator's Work-related Happiness" 71), in line with our previous research. In agreement with Klamár and Gavalová (329) who acknowledge inconsistencies in the methods of measurement of happiness, we propose our own framework, incorporating Dam and Zethsen's ("The Status of Professional Business Translators on the Danish Market: A Comparative Study of Company, Agency and Freelance Translators.") as well as our own variables (see section for 4).

\section{Methods}

The questionnaire underlying the present survey was composed in Google Forms and was organized into three thematic sections. The first section included background questions focusing on subjects' demographic information (employment type, age, sex, education etc.), the second section related to variables of occupational prestige (expertise, income, visibility, power/influence) by Dam and Zethsen ("The Status of Professional Business Translators on the Danish Market: A Comparative Study of Company, Agency and Freelance Translators.") and the third section dealt with the author's psychological variables of HAW comprising aspirations, linguistic hedonism, working environment and usefulness ${ }^{2}$ (see Bednárová-Gibová (a), "Exploring the Literary Translator's Work-related Happiness"). Based on a fusion of the given variables, we propose our own framework for testing translators' HAW, applied with modifications already to literary translators (ibid.) as well as their sworn and institutional peers (Bednárová-Gibová) in the Slovak translator landscape.

2 Some of these variables have been inspired by Veenhoven's psychological framework and subsequently adapted to the translator's habitus (see Author "Exploring the Literary Translator's Work-related Happiness" and Author forthcoming for more detail).

Cad. Trad., Florianópolis, v. 41, nº 2 p. 109-136, mai-ago, 2021. 
The questions in the second and third sections of the questionnaire used Likert-type scale items which were coded more or less as follows: 1 - to a very low degree, 2 - to a low degree, 3 - to a certain degree, 4 - to a high degree, 5 - to a very high degree. The last two questions were open-ended and qualitative, calling for a thematic analysis to be performed. The link to the e-questionnaire was distributed to 29 translation agencies and 201 freelancers whose e-mail addresses have been carefully selected online using the www.zoznam.sk website as well as social media (Facebook, Twitter) during two weeks in March and April 2020 throughout the COVID-19 pandemic. The Slovak Association of Translators and Interpreters (SAPT) also took part in the data collection process.

Through convenience and snowball sampling, a total of 179 responses were obtained. Of these, 2 responses of the agency translators had to be excluded from the sample because they failed to complete one whole section of the questionnaire. Thus, the survey is based on a sample of 177 respondents (93 agency translators, 84 freelancers).

Based on the study of psychological literature (Warr \& Inceoglu), it was hypothesized that freelancers as self-employed workers would show greater happiness scores than their agency peers. The paper addresses two research questions: What are the similarities and diffrences in the selected translator habitus in the perception of their occupational happiness? Which job satisfiers do they make use of when combating their professional realities and how does it influence their professional well-being?

In order to evaluate the respondents' data, a mixed-methods approach consisting of a combination of quantitative and qualitative methods is used. The data are analysed by measures of central tendency (so-called median values; Mdn) and are compared between the two cohorts.

We also calculated whether the differences in the respondents' answers were statistically significant for the tested variables, using independent t-tests. In the next step, we performed a correlation analysis of the data (see a list of contingency tables in the appendix). 
Statistical significance was calculated via Pearson's chi-square test $\left(\chi^{2}\right)$ where $p$-values under 0.05 are statistically significant. A qualitative analysis has been applied to the assessment of the respondents' open-ended questions.

\section{Results}

The translators' background profile reveals that the majority of both agency and freelance translators are female subjects working on a full-time basis. Half of the agency translators cohort are subjects in their $40 \mathrm{~s}$ and $30 \mathrm{~s}$ and $23.6 \%$ of the translators are in the 25-29 age range. By the same token, the overwhelming majority of freelancers $(63.1 \%)$ are translators in their 30 s and 40 s, with the proportion of young translators in their late twenties being nearly two times lower (13.1\%). This implies that younger translators could be slightly keener on working for translation agencies considering their early career possibilities. Participants in both cohorts are relatively well-educated; $55.9 \%$ of agency and $61.9 \%$ of freelance translators are M.A. degree holders in the humanities. There are also a comparable number of $\mathrm{PhD}$. degree holders $(10.7 \%$ vs. $13.1 \%)$ in both cohorts. An interesting profile trait of the agency subjects is that almost a third of them have been active translators for more than 21 years while a comparable number of their freelance peers for only 6-10 years. Whereas a third of agency translators $(32.3 \%)$ tend to work for more than 40 hours per week, half of freelancers translate either between 31-40 hours or $>40$ hours per week.

The subjects were asked to evaluate their self-perceptions of occupational prestige and psychological HAW variables, as explained in the Methods section. In regard to the degree of expertise necessary for carrying out translation jobs, agency translators (A) concur to an extent that translation requires a "high degree" of expertise, rating 4.24 on average $(M d n=4)$. Freelancers $(F)$, with the same median value of 4 (4.25), feel the same. We found no 
significant relationship between HAW and the translators' degree of expertise in either group by means of correlation analysis $\left(\mathrm{A}: \chi^{2}\right.$ $\left.=3.502, p=0.743, \mathrm{~F}: \chi^{2}=2.838, p=0.585\right)$, as evidenced in Tables 1 and 2 (see Appendix).

Income conventionally stands for the most important indicator of occupational prestige (Weiss-Gal; Welbourne). In terms of satisfaction with income, there is a statistically significant difference $(p=0.002)$ between agency translators $(3.33$; Mdn $=$ 4) and freelancers (3.75; Mdn=4). The latter appear more satisfied with their income although as few as $9.6 \%$ and $7.2 \%$ of freelancers can boast of earning more than 3,000 EUR and 2,000-3,000 EUR gross per month, respectively. ${ }^{3}$ Based on the data in Tables 3 and 4 , correlation analysis reveals that there is a significant relationship between HAW and the translators' satisfaction with income at the 0.01 significance level. We argue that in both cohorts HAW seems to be connected with satisfaction with salary $\left(\mathrm{A}: \chi^{2}=46.497, p=\right.$ $\left.0.00006, \mathrm{~F}: \chi^{2}=18.781, p=0.0045\right)$. However, a deeper analysis in the cohort of agency translators discloses their professional wellbeing does not relate only to a "high" income, but also to the sensation of accomplishment at work.

Translators' visibility as a multifaceted concept is approached in this study in the sense of professional, not physical visibility, echoing Venuti's original ruminations (1995). Similarly, both translators' marketing activities as well as memberships in professional bodies are left aside here. Freelancers (with an average of 2.63, Mdn = 2) report that their name 'sometimes' appears on final translations differing significantly from agency respondents (average 2.17, Mdn = 2) who 'seldom' experience this kind of visibility ( $p=$ 0.011). ${ }^{4}$ However, as can be inferred from Tables 5 and 6, there is no significant relationship between translators' HAW and their

3 The translators' income is to be compared with the estimated average pay in Slovakia in 2020 amounting to 1,163 EUR gross pay (https://www. minimalnamzda.sk/priemerna-mzda.php).

${ }^{4}$ This statistically confirmed situation was, however, more or less expected as agency translators remain usually hidden under the auspices of the agency.

Cad. Trad., Florianópolis, v. 41, n⿳ 2 p. 109-136, mai-ago, 2021. 
visibility (A: $\left.\chi^{2}=9.608, p=0.650, \mathrm{~F}: \chi^{2}=6.2, p=0.624\right)$; translators in both cohorts seem perfectly happy without their name appearing on final translations.

The questionnaire included an enquiry about translators' power/ influence. We explored power in the sense of translators' authority and autonomy manifested both internally (i.e. towards the text) and externally (towards other agents of translation process). In this vein, we digressed both from Tymoczko's (2014) all-encompassing understanding of the concept (involving linguistic, cultural, institutional and ethical aspects) and Dam and Zethsen's ("Translator Status. A Study of Danish Company Translators.") promotionoriented interpretation as a tool to change the individual's position in the translation company. Most agency and freelance translators opted for the neutral middle category $(\mathrm{Mdn}=3)$, i.e. 'average' power/influence, rating 3.00 and 3.13 on average, respectively. We found a significant relationship between HAW and the translator's power/influence at the 0.05 significance level in agency translators $\left(\chi^{2}=25.024, p=0.014\right)$. This means that the agency translators who possess some influence tend to show higher HAW scores. By contrast, a significant relationship between the tested variables was not confirmed in freelancers $\left(\chi^{2}=9.245, p=0.321\right)$.

Next, the subjects were asked to what extent their aspirations when performing translation jobs were fulfilled. The subjects' answers indicate that most translators experience relatively high levels of fulfilment of their professional aspirations $(\mathrm{Mdn}=4)$, with an agency average of 3.60 and a freelance average of 3.71. The correlation analysis reveals a significant relationship at the 0.01 significance level in both cohorts (A: $\chi^{2}=38.933, p=0.00012, \mathrm{~F}$ : $\left.\chi^{2}=35.349, p=0.00004\right)$. Hence, the subjects whose aspirations at work have been met to a 'very high' or 'high degree' seem happier (see Tables 9 and 10).

It was also enquired of the subjects how often they experience what we dub 'linguistic hedonism', that is the feeling of pleasure coming from working with words (see Bednárová-Gibová, "Exploring the Literary Translator's Work-related Happiness"). 
The average response in agency translators was 3.34, i.e. 'half of the time' whereas freelancers averaged slightly higher, 3.58 $(\mathrm{Mdn}=4)$ although the difference was not statistically significant. Intriguingly, as Tables 11 and 12 show, we found a significant relationship between HAW and linguistic hedonism in freelancers $\left(\chi^{2}=24.932, p=0.0015\right)$. This group of translators seems to experience a higher degree of linguistic pleasure when doing 'interlanguaging', which furnishes them with a sense of professional well-being. On the other hand, agency translators seem happy without revelling in linguistic hedonism $\left(\chi^{2}=15.383, p=0.221\right)$.

Working environment emerged as an important HAW parameter since both cohorts of translators seem happier providing that their working environment is "stimulating" (A: $\chi^{2}=17.703, p$ $\left.=0.038, \mathrm{~F}: \chi^{2}=24.654, p=0.0003\right)$. Positive perceptions of working environment are evinced in the subjects' answers of agency translators scoring 3.49 and freelancers 3.67 on average $(\mathrm{Mdn}=4)$.

Last but far from least, in response to the question "how useful do you feel in your life as a translator?" agency participants had the same average ratings $(4.02 ; M d n=4)$ with freelancers. This suggests a positive sense of usefulness in translators' professional lives. HAW and translators' usefulness stand out as attributes which seem to be closely linked. Based on the data in Tables 15 and 16, there is a significant relationship between the tested variables at the 0.01 significance level in both agency translators and freelancers $\left(\mathrm{A}: \chi^{2}=30.272, p=0.00039\right.$, F : $\left.\chi^{2}=25.632, p=0.000038\right)$. This testifies to the fact that the subjects in both groups seem happier if they feel useful in their professional lives.

Furthermore, we looked at the translators' job satisfiers. Both agency translators and freelancers seek the major resources of their job satisfaction in their 'ability to do quality translations' as well as in the 'increase in knowledge and skills' which comes with translating (see Figures 1-2). As the data suggest, to agency translators the 'ability to meet clients'/recipients' expectations' matters more than to freelancers. On the other hand, 'respect and recognition' comes as a more important job satisfier in freelancers. 
Figure 1: Major resources of job satisfaction (absolute frequencies) - agency translators

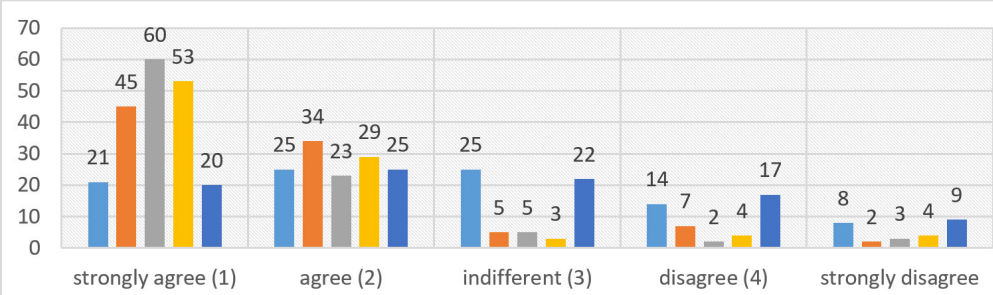

(5)

$$
\begin{aligned}
& \text { - respect and recognition ability to meet expectations } \\
& \text { ability to do quality translations } \mathbf{m} \text { increase in knowledge and skills } \\
& \text { well-paid and responsible job }
\end{aligned}
$$

Source: the authors.

Figure 2: Major resources of job satisfaction (absolute frequencies) - freelancers

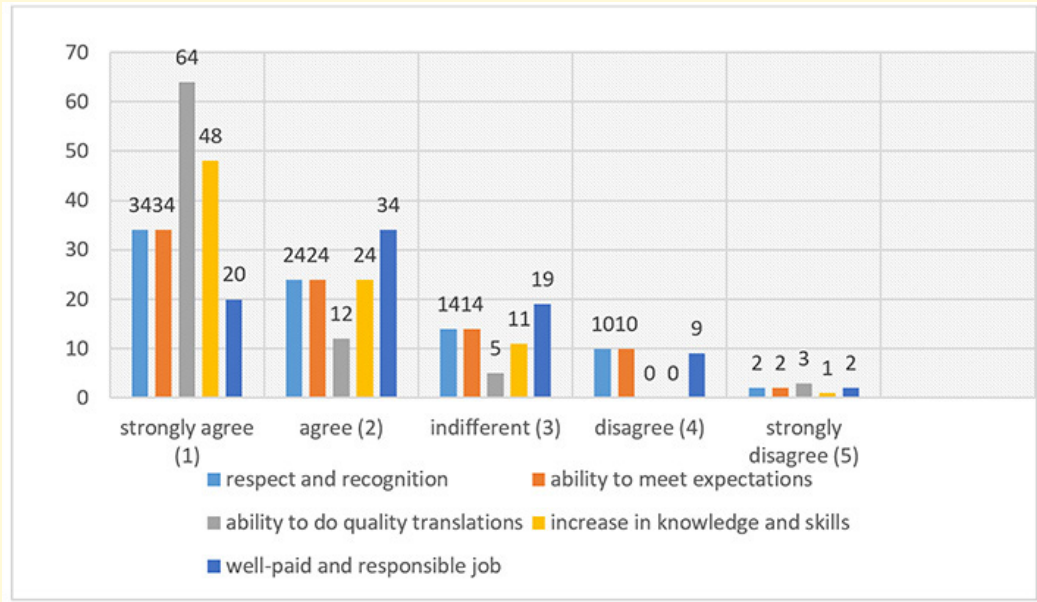

Source: the authors.

In addition, a qualitative analysis of the subjects' open-ended questions on what would increase their professional well-being 
does disclose cravings for a better income and relationships between the translation market players. A good many agency translators would unanimously welcome a higher salary, less urgent deadlines and a more balanced relationship between agency clients and suppliers. Freelancers particularly feel that they lack better remuneration, reliable business partners and regular translation commissions. The cooperation aspect of the translation job is seen critically by an anonymous freelancer who resentfully mentions that "some translators attempt to create long-term relationships with commissioners even at the cost of not being able to deal with the amount of translation work, trying to gain control of the commissioner market in a dishonest way, getting in touch with other translators working for them for an agreed reward." A number of freelancers also mention exploitation practices of translation agencies decreasing their HAW, e.g., "agency translations are equal to $50 \%$ theft". On the other hand, some freelancers openly admit to their linguistic hedonism, giving them a sense of professional well-being. This is documented by the following anonymous respondent: "There are colocations which can still make me feel delighted or keep me surprised; I can become enthralled by the foreign language I have a command of to some extent".

\section{Discussion}

Overall, the results of this survey indicate that both agency and freelance translators exhibit "high" levels of professional wellbeing (the average ratings for agency translators are 3.96 compared to 4.13 in freelancers; $M d n=4)$. These empirical findings are commensurate with the results reported in wider TS literature (e.g., Katan, "Translation Theory and Professional Practice" and "Occupation or Profession"; Dam \& Zethsen, "I Think It Is a Wonderful Job"; Rodríguez-Castro, "Extrinsic and Intrinsic Sources"; Courtney \& Phelan; Bednárová-Gibová \& Madoš) that translators appear gratified in their translation jobs. In this sense the 
present study contributes to a growing body of empirical evidence on the issue at hand. Based on the high levels of professional wellbeing in both groups of participants, the directional hypothesis underlying this study was not borne out; it cannot be irrevocably claimed that freelancers are professionally happier than their agency peers.

Our data indicate that with the exception to the questions on the translator's satisfaction with income and visibility there were nonsignificant differences in the respondents' answers. This means that both groups of participants have approximately the same selfconcepts of the examined parameters. It should be mentioned, however, that freelancers evince slightly higher mean ratings of their perceived levels of happiness, influence/power, aspirations, linguistic hedonism and working environment. In marked contrast to the results of the flagship study by Dam and Zethsen ("The Status of Professional Business Translators on the Danish Market: A Comparative Study of Company, Agency and Freelance Translators."), freelancers in this study have a higher degree of visibility and power/influence than their agency peers. Unlike Moorken's research, our freelancers' self-concepts of usefulness (or "purpose" in his own words) and satisfaction with income do not compare poorly with agency translators.

We found significant relationships between HAW and translators' satisfaction with income, aspirations, working environment and usefulness in both cohorts. These results imply that income as a hard-core status parameter is not to be overlooked in the tested translators, and especially in freelancers who are self-employed individuals earning a living. This contrasts well with literary translators who show a proclivity to conceptualize their work as a vocation and an artistic activity, denouncing remuneration as a status indicator (Sela-Sheffy, "'Stars' or 'Professionals"” and "Elite and Non-elite Translator Manpower"). Professional aspirations of translators connected to their carrying out translation tasks in a dignified working environment (whatever that means depending on the individual's level of requirements) are not to be underestimated, 
either. The importance of usefulness in one's life, as evidenced in this study, is also emphasized in the latest Job Satisfaction Index (Krifa) when promoting meaning in human beings' activities. On the other hand, the relationships between HAW and translators' degree of expertise and visibility turned out to be non-significant for both cohorts.

Although we found that both groups of translators experience comparable levels of domain-specific happiness they differ in its two facet-specific features, that is power/influence and linguistic hedonism. Whereas in agency translators power/influence makes for a fairly important HAW determinant, it is non-significant in freelancers. This could be related to agency translators' clandestine cravings to have power not only over a text (that is inwards), but also over other players of translation process such as commissioners, colleagues, co-translators and so forth, which is not always possible when working for a translation agency. A salient difference concerning the subjects' linguistic hedonism is that it makes a crucial HAW determinant for freelancers only. This could be motivated by freelancers' greater propensity for linguistic pleasures when translating as sole traders, and thus "for themselves", when compared to agency translators whose performance-driven status in the company could be somewhat detrimental, pushing their affections for wordsmithery aside. However, more in-depth research is required in order to be able to confirm this preliminary hypothesis. Regardless of the ascertained points of contrast concerning the facet-specific happiness in the two groups, we contend that there are far more commonalities in the self-perceptions of their professional well-being than differences.

The study's findings also show that the translators' major resources of job satisfaction are connected to inward-oriented work achievement such as dealing with translations and increasing one's knowledge rather than outward work orientations (respect and clients' expectations). Since the self-centred personality trait was ascertained also in sworn and institutional translators (BednárováGibová \& Madoš) as well as their literary peers (Bednárová-Gibová, 
"Exploring the Literary Translator's Work-related Happiness"), it seems to be an immanent feature of the Slovak translators' habitus. For reasons of cross-national generalizations, it would be tempting to carry out further research above the national translator landscape to (dis-)confirm this psychological tendency.

\section{Conclusion}

To conclude, the results reported in this study highlight some intriguing dependencies between translators' self-concepts of status parameters, psychological variables of HAW and professional wellbeing. Status parameters of 'western' TS as well as psychological attributes of HAW have been transposed to the Slovak translator space, offering a contemporary socio-psychological view of the (semi-)profession of agency and freelance translators. Having digressed from a conventional line of translator identity investigation, occupation-driven research in TS can help us better understand how translators' values and attitudes are construed. Grasping translators' sources of job satisfaction seems crucial for enhancing translator productivity and professional well-being. Ultimately, agent-grounded research of this sort can cast a spotlight on the proverbial driving wheels for translators en route to their professional well-being and help to overcome the gaping chasm between translators' enjoyment of their jobs and their nagging societal misrecognition. On a longitudinal basis, the results of this study can contribute to the research on translators' professional well-being in major linguocultures providing that comparative perspectives are used not only cross-nationally but also crosshabitus-wise, incorporating various translator types. 


\section{References}

Bednárová-Gibová, Klaudia. "Exploring the Literary Translator's Work-related Happiness: the Case Study of Slovakia." Across Languages and Cultures. A Multidisciplinary Journal for Translation and Interpreting Studies, vol. 21, $\mathrm{n}^{\mathrm{o}}$. 1, (2020): 67-87.

Bednárová-Gibová, Klaudia. "How Happy are Legal Translators at their Work? Further Insights from a Cognitive-Affective Enquiry." Translation Studies, 2022 (forthcoming).

Bednárová-Gibová, Klaudia; Madoš, Branislav. "Investigating Translators' Work-related Happiness: Slovak Sworn and Institutional Translators as a Case in Point." Meta: Journal des traducteurs /Translators' Journal, vol. 64, ${ }^{o}$. 1, (2019): 215-241.

Bolaños-Medina, Alicia. "Translation Psychology within the Framework of Translation Studies: New Research Perspectives and Pedagogical Implications." From the Lab to the Classroom and Back Again, edited by Celia Martín de León and Víctor González-Ruiz, Frankfurt am Main: Peter Lang, 2016, pp. 59-99.

Chesterman, Andrew. "The Name and Nature of Translator Studies." Hermes Journal of Language and Communication Studies, $\mathrm{n}^{\mathrm{o}}$. 42, (2009): 13-22.

Chesterman, Andrew. "Moving Conceptual Boundaries: So What?" Moving Boundaries in Translation Studies, edited by Helle V. Dam, Matilde Nisbeth Brøgger and Karen Korning Zethsen. Moving Boundaries in Translation Studies, London: Routledge, 2019, pp.12-25.

Courtney, Jennifer; Phelan, Mary. "Translators' Experiences of Occupational Stress and Job Satisfaction." Translation \& Interpreting, vol. 11, $\mathrm{n}^{\circ}$. 1, (2019): $100-113$.

Dam, Helle V.; Zethsen, Karen K. "Translator Status. A Study of Danish Company Translators." The Translator, vol. 14, no.1, 2008: 71-96. 
Dam, Helle V.; Zethsen, Karen K. "The Status of Professional Business Translators on the Danish Market: A Comparative Study of Company, Agency and Freelance Translators." Meta: Journal des traducteurs /Translators' Journal, vol. 56, no.4, 2011: 976-997.

Dam, Helle V.; Zethsen, Karen K. "I Think It Is a Wonderful Job". On the Solidity of the Translation Profession." The Journal of Specialized Translation, no. 25, 2016: 174-187.

Jackson, Beau. "Freelancers Report High Job Satisfaction". HR Magazine, (2020). available at https://www.hrmagazine.co.uk/article-details/freelancersreport-high-job-satisfaction. Accessed 16 June 2020.

Katan, David. "Translation Theory and Professional Practice: A Global Survey of the Great Divide." Hermes - Journal of Language and Communication Studies, no. 42, 2009: 111-153.

Katan, David. "Occupation or Profession. A Survey of the Translators' World." Identity and Status in the Translational Professions, edited by Rakefet Sela-Sheffy and Miriam Shlesinger, Amsterdam: John Benjamins, 2011, p. 65-88.

Klamár, Radoslav; Gaval’ová, Anna. "Regional Application of the Gross National Happiness Index in the Context of the Quality of Life in Slovakia." Geograficky časopis, vol. 70, no. 4, 2018: 315-333.

Krifa. Job Satisfaction Index. Your Life - Your Job satisfaction (Report). Copenhagen: Happiness Research Institute, 2019.

Liu, Fung Ming Christy. "A Quantitative Enquiry into the Translator's Job-Related Happiness: Does Visibility Correlate with Happiness?”. Across Languages and Cultures. A Multidisciplinary Journal for Translation and Interpreting Studies, vol. 14, $\mathrm{n}^{\mathrm{o}} .1$, (2013): 123-147.

Moorkens, Joss. "Comparative Satisfaction among Freelance and Directlyemployed Irish-Language Translators." Translation \& Interpreting, vol. 12, $\mathrm{n}^{\mathrm{0}}$. 1, (2019): 55-73. 
Ng, Thomas W. H.; Feldman, Daniel C. "Subjective Career Success: A Metaanalytic Review." Journal of Vocational Behaviour, vol. 85, $\mathrm{n}^{\circ}$. 2, (2014): 169179.

Rodríguez-Castro, Mónica. "Development and Empirical Validation of a Multifaceted Instrument for Translator Satisfaction. " Translation \& Interpreting, vol. 7, $\mathrm{n}^{\mathrm{o}} .2$, (2015): 1-21.

Rodríguez-Castro, Mónica. "Intrinsic and Extrinsic Sources of Translator Satisfaction: An Empirical Study." Entreculturas, nº. 7-8, (2016): 195-229.

Ruokonen, Minna; Mäkisalo, Jukka. "Middling-Status Profession, High Status Work: Finnish Translators' Status Perceptions in the Light of Their Backgrounds, Working Conditions and Job Satisfaction. Translation \& Interpreting, vol. 10, $\mathrm{n}^{\mathrm{0}} .1$, (2018): 1-17.

Ruokonen, Minna.; Lassus, Jannika; Virtanen, Taru. “'I Fulfil My Place among the Humankind, in the Universe'. Finnish Translators' Job Satisfaction in Three Empirical Studies." Electronic Journal of the KäTu Symposium on Translation and Interpreting Studies, vol. 13, (2020): 109-123.

Salas-Vallina, Andrés; Alegre Joaquín; Guerrero, Rafael Fernández. "Happiness at Work in Knowledge-Intensive Contexts: Opening the Research Agenda." European Research on Management and Business Economics, vol. 24, no. 3, 2018: 149-159.

Sela-Sheffy, Rakefet. "'Stars' or 'Professionals': The Imagined Vocation and Exclusive Knowledge of Translators in Israel." Applied Sociology in Translation Studies, edited by Oscar D. Fouces and Esther Monzó, Alicante: Publicationes de la Universidad de Alicante, 2010, p. 131-152.

Sela-Sheffy, Rakefet. "Elite and Non-Elite Translator Manpower: The NonProfessionalised Culture in the Translation Field in Israel." Journal of Specialised Translation, $\mathrm{n}^{\circ} .25,(2016)$ : 54-73.

Tymoczko, Maria. Enlarging Translation, Empowering Translators. New York: Routledge, 2014. 
Venuti, Lawrence. The Translators' Invisibility. A History of Translation. New York: Routledge, 1995.

Warr, Peter. Work, Happiness, Unhappiness. Mahwah: Lawrence Erlbaum, 2007.

Warr, Peter. "Searching for Happpiness at Work." The Psychologist, vol. 20, no. 12, 2007: 726-729.

Warr, Peter. The Psychology of Happiness. London: Routledge, 2019.

Warr, Peter; Inceoglu, Ilke. "Work Orientations, Well-Being and Job Content of Self-Employed and Employed Professionals." Work, Employment, Society, vol. 32, no. 2, 2018: 292-311.

Warr, Peter; Nielsen, Karina. "Well-Being and Work Performance." Handbook of Well-being, edited by Ed Diener, Shigehiro Oishi and Louis Tay, Salt Lake City, UT: DEF Publishers, 2018, available at https://www.nobascholar.com/ chapters/69. Accessed 21 June 2020.

Weiss-Gal, Idit; Welbourne, Penelope. "The Professionalisation of Social Work: a Cross-National Exploration." International Journal of Social Welfare, vol.17, no. 4, 2008: 281-290.

Recebido em: 13/11/2020

Aceito em: 22/03/2021

Publicado em maio de 2021

Klaudia Bednárová-Gibová. E-mail: klaudia.gibova@gmail.com. ORCID: http:// orcid.org/0000-0002-6555-4464.

Mária Majherová. E-mail: maria.majherova@unipo.sk. ORCID: https://orcid. org/0000-0003-3097-778X. 


\section{APPENDIX: LIST OF CONTINGENCY TABLES}

Table 1: Correlation between HAW and expertise - agency translators

\begin{tabular}{|l|l|l|l|l|l|}
\hline Expertise & Very high & High & Average & Low & Low \\
\hline Very happy & 9 & 13 & 1 & 0 & 0 \\
\hline Happy & 15 & 27 & 4 & 0 & 0 \\
\hline $\begin{array}{l}\text { Neither happy nor } \\
\text { unhappy }\end{array}$ & 7 & 11 & 3 & 0 & 0 \\
\hline Unhappy & 1 & 1 & 1 & & 0 \\
\hline Very unhappy & 0 & 0 & 0 & 0 & 0 \\
\hline
\end{tabular}

Table 2: Correlation between HAW and expertise - freelancers

\begin{tabular}{|l|l|l|l|l|l|}
\hline Expertise & Very high & High & Average & Low & Low \\
\hline Very happy & 13 & 17 & 1 & 0 & 0 \\
\hline Happy & 9 & 21 & 3 & 0 & 0 \\
\hline $\begin{array}{l}\text { Neither happy nor } \\
\text { unhappy }\end{array}$ & 5 & 13 & 2 & 0 & 0 \\
\hline Unhappy & 0 & 0 & 0 & 0 & 0 \\
\hline Very unhappy & 0 & 0 & 0 & 0 & 0 \\
\hline
\end{tabular}

Table 3: Correlation between HAW and satisfaction with income - agency translators

\begin{tabular}{|l|l|l|l|l|l|}
\hline Satisfaction & Very high & High & Average & Dissatisfied & $\begin{array}{l}\text { Very } \\
\text { dissatisfied }\end{array}$ \\
\hline Very happy & 8 & 10 & 3 & 1 & 1 \\
\hline Happy & 0 & 21 & 17 & 8 & 0 \\
\hline $\begin{array}{l}\text { Neither happy nor } \\
\text { unhappy }\end{array}$ & 1 & 7 & 4 & 8 & 1 \\
\hline Unhappy & 0 & 0 & 0 & 2 & 1 \\
\hline
\end{tabular}




\begin{tabular}{|l|l|l|l|l|l|}
\hline Very unhappy & 0 & 0 & 0 & 0 & 0 \\
\hline
\end{tabular}

Table 4: Correlation between HAW and satisfaction with income - freelancers

\begin{tabular}{|l|l|l|l|l|l|}
\hline Satisfaction & $\begin{array}{l}\text { Very } \\
\text { high }\end{array}$ & High & Average & Dissatisfied & $\begin{array}{l}\text { Very } \\
\text { dissatisfied }\end{array}$ \\
\hline Very happy & 10 & 16 & 4 & 1 & 0 \\
\hline Happy & 2 & 19 & 9 & 3 & 0 \\
\hline $\begin{array}{l}\text { Neither happy nor } \\
\text { unhappy }\end{array}$ & 1 & 7 & 11 & 1 & 0 \\
\hline Unhappy & 0 & 0 & 0 & 0 & 0 \\
\hline Very unhappy & 0 & 0 & 0 & 0 & 0 \\
\hline
\end{tabular}

Table 5: Correlation between HAW and visibility - agency translators

\begin{tabular}{|l|l|l|l|l|l|}
\hline Visibility & Very often & Often & Sometimes & Rarely & Never \\
\hline Very happy & 1 & 3 & 5 & 9 & 5 \\
\hline Happy & 4 & 4 & 6 & 18 & 14 \\
\hline $\begin{array}{l}\text { Neither happy nor } \\
\text { unhappy }\end{array}$ & 0 & 1 & 5 & 5 & 10 \\
\hline Unhappy & 0 & 0 & 0 & 1 & 2 \\
\hline Very unhappy & 0 & 0 & 0 & 0 & 0 \\
\hline
\end{tabular}

Table 6: Correlation between HAW and visibility - freelancers

\begin{tabular}{|l|l|l|l|l|l|}
\hline Visibility & Very often & Often & Sometimes & Rarely & Never \\
\hline Very happy & 4 & 8 & 7 & 6 & 6 \\
\hline Happy & 1 & 5 & 7 & 13 & 7 \\
\hline $\begin{array}{l}\text { Neither happy nor } \\
\text { unhappy }\end{array}$ & 2 & 2 & 5 & 7 & 4 \\
\hline Unhappy & 0 & 0 & 0 & 0 & 0 \\
\hline Very unhappy & 0 & 0 & 0 & 0 & 0 \\
\hline
\end{tabular}


Table 7: Correlation between HAW and power/influence - agency translators

\begin{tabular}{|l|l|l|l|l|l|}
\hline Power & Very high & High & Average & Low & Very low \\
\hline Very happy & 2 & 11 & 7 & 2 & 1 \\
\hline Happy & 1 & 11 & 23 & 10 & 1 \\
\hline $\begin{array}{l}\text { Neither happy nor } \\
\text { unhappy }\end{array}$ & 2 & 1 & 9 & 4 & 5 \\
\hline Unhappy & 0 & 0 & 1 & 1 & 1 \\
\hline Very unhappy & 0 & 0 & 0 & 0 & 0 \\
\hline
\end{tabular}

Table 8: Correlation between HAW and power/influence - freelancers

\begin{tabular}{|l|l|l|l|l|l|}
\hline Power & Very high & High & Average & Low & Very low \\
\hline Very happy & 5 & 6 & 16 & 3 & 1 \\
\hline Happy & 3 & 8 & 17 & 3 & 2 \\
\hline $\begin{array}{l}\text { Neither happy } \\
\text { nor unhappy }\end{array}$ & 0 & 4 & 8 & 5 & 3 \\
\hline Unhappy & 0 & 0 & 0 & 0 & 0 \\
\hline Very unhappy & 0 & 0 & 0 & 0 & 0 \\
\hline
\end{tabular}

Table 9: Correlation between HAW and aspirations - agency translators

\begin{tabular}{|l|l|l|l|l|l|}
\hline Aspirations & Very high & High & To some extent & Low & Very low \\
\hline Very happy & 6 & 13 & 4 & 0 & 0 \\
\hline Happy & 5 & 25 & 15 & 1 & 0 \\
\hline $\begin{array}{l}\text { Neither happy } \\
\text { nor unhappy }\end{array}$ & 1 & 3 & 11 & 6 & 0 \\
\hline Unhappy & 0 & 0 & 1 & 2 & 0 \\
\hline Very unhappy & 0 & 0 & 0 & 0 & 0 \\
\hline
\end{tabular}

Table 10: Correlation between HAW and aspirations - freelancers

\begin{tabular}{|l|l|l|l|l|l|}
\hline Aspirations & Very high & High & To some extent & Low & Very low \\
\hline Very happy & 13 & 16 & 2 & 0 & 0 \\
\hline Happy & 3 & 10 & 19 & 1 & 0 \\
\hline
\end{tabular}




\begin{tabular}{|l|l|l|l|l|l|}
\hline $\begin{array}{l}\text { Neither happy } \\
\text { nor unhappy }\end{array}$ & 0 & 4 & 15 & 1 & 0 \\
\hline Unhappy & 0 & 0 & 0 & 0 & 0 \\
\hline Very unhappy & 0 & 0 & 0 & 0 & 0 \\
\hline
\end{tabular}

Table 11: Correlation between HAW and linguistic hedonism agency translators

\begin{tabular}{|l|l|l|l|l|l|}
\hline Hedonism & Often & $\begin{array}{l}\text { Most of the } \\
\text { time }\end{array}$ & $\begin{array}{l}\text { Half of } \\
\text { the time }\end{array}$ & Sometimes & $\begin{array}{l}\text { Seldom/ } \\
\text { Never }\end{array}$ \\
\hline Very happy & 6 & 11 & 4 & 2 & 0 \\
\hline Happy & 2 & 21 & 12 & 9 & 2 \\
\hline $\begin{array}{l}\text { Neither happy } \\
\text { nor unhappy }\end{array}$ & 1 & 6 & 7 & 5 & 2 \\
\hline Unhappy & 0 & 1 & 1 & 1 & 0 \\
\hline Very unhappy & 0 & 0 & 0 & 0 & 0 \\
\hline
\end{tabular}

Table 12: Correlation between HAW and linguistic hedonism freelancers

\begin{tabular}{|l|l|l|l|l|l|}
\hline Hedonism & Often & $\begin{array}{l}\text { Most of the } \\
\text { time }\end{array}$ & $\begin{array}{l}\text { Half of } \\
\text { the time }\end{array}$ & Sometimes & $\begin{array}{l}\text { Seldom/ } \\
\text { Never }\end{array}$ \\
\hline Very happy & 8 & 20 & 1 & 2 & 0 \\
\hline Happy & 1 & 17 & 10 & 5 & 0 \\
\hline $\begin{array}{l}\text { Neither happy } \\
\text { nor unhappy }\end{array}$ & 2 & 5 & 6 & 6 & 1 \\
\hline Unhappy & 0 & 0 & 0 & 0 & 0 \\
\hline Very unhappy & 0 & 0 & 0 & 0 & 0 \\
\hline
\end{tabular}


Table 13: Correlation between HAW and working environment agency translators

\begin{tabular}{|c|c|c|c|c|c|}
\hline 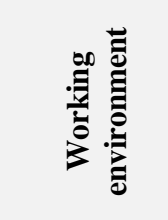 & 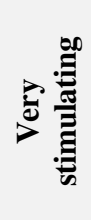 & 告 & 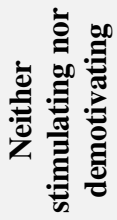 & 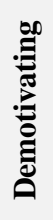 & 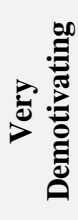 \\
\hline Very happy & 2 & 16 & 5 & 0 & 0 \\
\hline Happy & 1 & 21 & 21 & 3 & 0 \\
\hline $\begin{array}{l}\text { Neither } \\
\text { happy nor } \\
\text { unhappy }\end{array}$ & 2 & 5 & 12 & 2 & 0 \\
\hline Unhappy & 0 & 0 & 2 & 1 & 0 \\
\hline $\begin{array}{l}\text { Very } \\
\text { unhappy }\end{array}$ & 0 & 0 & 0 & 0 & 0 \\
\hline
\end{tabular}

Table 14: Correlation between HAW and working environment freelancers

\begin{tabular}{|c|c|c|c|c|c|}
\hline 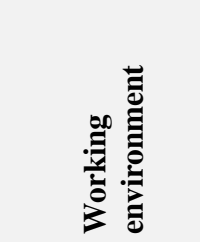 & 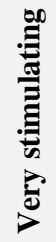 & 咆 & 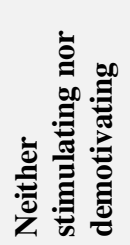 & 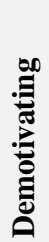 & 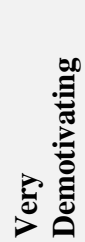 \\
\hline Very happy & 10 & 14 & 7 & 0 & 0 \\
\hline Happy & 0 & 15 & 18 & 0 & 0 \\
\hline $\begin{array}{l}\text { Neither happy } \\
\text { nor unhappy }\end{array}$ & 0 & 9 & 10 & 1 & 0 \\
\hline Unhappy & 0 & 0 & 0 & 0 & 0 \\
\hline Very unhappy & 0 & 0 & 0 & 0 & 0 \\
\hline
\end{tabular}


Table 15: Correlation between HAW and usefulness - agency translators

\begin{tabular}{|l|l|l|l|l|l|}
\hline Usefulness & $\begin{array}{l}\text { Very } \\
\text { useful }\end{array}$ & Useful & $\begin{array}{l}\text { Neither } \\
\text { useful nor } \\
\text { unimportant }\end{array}$ & Unimportant & $\begin{array}{l}\text { Very } \\
\text { unimportant }\end{array}$ \\
\hline Very happy & 9 & 14 & 0 & 0 & 0 \\
\hline Happy & 8 & 34 & 3 & 1 & 0 \\
\hline $\begin{array}{l}\text { Neither } \\
\text { happy nor } \\
\text { unhappy }\end{array}$ & 2 & 11 & 7 & 1 & 0 \\
\hline Unhappy & 0 & 1 & 1 & 1 & 0 \\
\hline $\begin{array}{l}\text { Very } \\
\text { unhappy }\end{array}$ & 0 & 0 & 0 & 0 & 0 \\
\hline
\end{tabular}

Table 16: Correlation between HAW and usefulness - freelancers

\begin{tabular}{|l|l|l|l|l|l|}
\hline Usefulness & $\begin{array}{l}\text { Very } \\
\text { useful }\end{array}$ & Useful & $\begin{array}{l}\text { Neither } \\
\text { useful nor } \\
\text { unimportant }\end{array}$ & Unimportant & $\begin{array}{l}\text { Very } \\
\text { unimportant }\end{array}$ \\
\hline Very happy & 11 & 20 & 0 & 0 & 0 \\
\hline Happy & 3 & 26 & 4 & 0 & 0 \\
\hline $\begin{array}{l}\text { Neither } \\
\text { happy nor } \\
\text { unhappy }\end{array}$ & 0 & 12 & 8 & 0 & 0 \\
\hline Unhappy & 0 & 0 & 0 & 0 & 0 \\
\hline $\begin{array}{l}\text { Very } \\
\text { unhappy }\end{array}$ & 0 & 0 & 0 & 0 & 0 \\
\hline
\end{tabular}

